OPEN ACCESS

Edited by: Klaus Birkhofer, Lund University, Sweden

Reviewed by: José Manuel Mirás-Avalos, Centro de Edafología y Biología Aplicada del Segura (CSIC), Spain

Fernando José Cebola Lidon, Faculdade de Ciências e Tecnologia da Universidade Nova de Lisboa, Portugal

*Correspondence: William F. Schillinger william.schillinger@wsu.edu

Specialty section: This article was submitted to Agroecology and Land Use Systems,

a section of the journal

Frontiers in Ecology and Evolution

Received: 18 February 2017 Accepted: 21 April 2017

Published: 10 May 2017

Citation:

Schillinger WF (2017) Winter Pea: Promising New Crop for Washington's Dryland Wheat-Fallow Region.

Front. Ecol. Evol. 5:43. doi: 10.3389/fevo.2017.00043

\section{Winter Pea: Promising New Crop for Washington's Dryland Wheat-Fallow Region}

\author{
William F. Schillinger* \\ Department of Crop and Soil Sciences, Washington State University, Dryland Research Station, Lind, WA, USA
}

A 2-year tillage-based winter wheat (Triticum aestivum L.)-summer fallow (WW-SF) rotation has been practiced by the vast majority of farmers in the low-precipitation $(<300$ mm annual) rainfed cropping region of east-central Washington and north-central Oregon for 140 years. Until recently, alternative crops (i.e., those other than WW) so far tested have not been as economically viable or stable as WW-SF. A 6-year field study was conducted near Ritzville, WA (292 mm avg. annual precipitation) to determine the yield and rotation benefits of winter pea (Pisum sativum L.) (WP). Two 3-year rotations were evaluated: WP-spring wheat (SW)-SF vs. WW-SW-SF. Winter pea yields averaged 2,443 vs. 4,878 kg/ha for WW. No fertilizer was applied to WP whereas $56 \mathrm{~kg} \mathrm{~N}$ and $11 \mathrm{~kg}$ S/ha were applied to WW. Winter pea used significantly less soil water than WW. Over the winter months, a lesser percentage of precipitation was stored in the soil following WP compared to WW because: (i) very little WP residue remained on the soil surface after harvest compared to WW, and (ii) the drier the soil, the more precipitation is stored in the soil over winter. However, soil water content in the spring was still greater following WP vs. WW. Soil residual N in the spring (7 months after the harvest of WP and WW) was greater in WP plots despite not applying fertilizer to produce WP. Spring wheat grown after both WP and WW received the identical quantity of N, P, and S fertilizer each year. Average yield of SW was 2,298 and 2,011 kg/ha following WP and WW, respectively $(P<0.01)$. Adjusted gross economic returns for these two rotation systems were similar. Based partially on the results of this study, numerous farmers in the dry WW-SF region have shown keen interest in WP and acreage planted WP in east-central Washington has grown exponentially since 2013. This paper provides the first report of the potential for WP in the typical WW-SF region of the inland Pacific Northwest (PNW).

Keywords: winter pea, Inland Pacific Northwest USA, dryland cropping systems, winter wheat-summer fallow, crop diversification

\section{INTRODUCTION}

A monoculture WW-SF rotation is the dominant cropping system practiced by farmers on 1.5 million cropland hectares in east-central Washington and north-central Oregon. Researchers and farmers have experimented with numerous crops and rotations over many decades, but none have been found to be as stable, reliable, and profitable as WW-SF (Juergens et al., 2004). Grassy weeds, mostly downy brome (Bromus tectorum L.) and jointed goatgrass (Aegilops cylindrica Host.), are a huge problem with monoculture WW-SF. Many farmers have resorted to the "Clearfield"TM system 
for WW production that depends on use of the long soil-residual imazamax herbicide to control grassy weeds. A viable, stable, and profitable broadleaf crop is much needed for crop diversity and grassy weed control without the use of soil-residual herbicides.

Pulse crops are cool-season annual grain legumes mostly grown in the northern tier states of North Dakota and Montana, the high-precipitation ( $>450 \mathrm{~mm}$ average annual) Palouse region of Washington and Idaho (NASS, 2017), and the Canadian provinces of Alberta, Saskatchewan, and Manitoba (Statistics Canada, 2017). During the past 20 years, pulse crops have become an integral component of diversified and profitable dryland cropping systems in the Canadian and US northern Great Plains (Miller et al., 2003, 2015; Chen et al., 2006; Long et al., 2014).

In the PNW Palouse region, dry edible spring pea is commonly grown in rotation with wheat, with 48,000 ha of this crop harvested in 2016 (NASS, 2017). However, very little spring pea is produced in PNW areas that receive $<450 \mathrm{~mm}$ annual precipitation. Experience in east-central Washington has demonstrated that water and heat stresses during flowering and pod fill limits yield potential of spring pea whereas WP better avoids such abiotic stresses by reaching physiological maturity before the onset of high air temperatures (Nelson, 2017).

Chen et al. (2006) reported that fall-planted WP in the highprecipitation Palouse of the PNW yielded as much as 1,830 $\mathrm{kg} / \mathrm{ha}$ more than spring-planted pea cultivars. This (Chen et al., 2006) is the only published paper of such nature on WP in the PNW. Such observations of higher yield potential with WP compared to spring pea are not in general agreement with the much more comprehensive data sets from the Canadian and US northern Great Plains where winter temperatures are considerably colder than in the PNW. Chen et al. (2006) found that WP cultivars did not have a yield advantage over spring pea in central and south-central Montana. Similarly Strydhorst et al. (2015) recommended that farmers consider WP over spring pea only in the southernmost locations in Alberta. Although edible dry pea was harvested on 206,000 ha in Montana in 2016 (NASS, 2017) only about one percent of this was WP (P.R. Miller, personal communication).

Essentially no edible WP was produced anywhere in the PNW, (including the typical WW-SF region that receives $<300 \mathrm{~mm}$ average annual precipitation, prior to 2012. Field research (this study) conducted since 2010 near Ritzville, WA (292 mm annual average precipitation) has demonstrated that WP is well-suited for the low-precipitation drylands. Winter pea plantings in the WW-SF region have gone from basically zero to 2,730 hectares from 2013 to 2017 (Howard Nelson, personal communication). Although the land area planted to WP currently is still small, the annual increase in planted hectares has been exponential during this 5-year period. The objective of the 6-year study reported here was to determine the yield potential and yield stability of WP and associated rotation benefits to the subsequent crop compared to WW in the low-precipitation WW-SF region of east-central Washington.

Abbreviations: PNW, inland Pacific Northwest; SF, summer fallow; SW, spring wheat; WP, winter pea; WW, winter wheat.

\section{MATERIALS AND METHODS}

A long-term WP cropping systems experiment was initiated at the Ronald Jirava farm near Ritzville, WA (47.16394,118.473225) in August 2010. The WP cultivar "Windham" (McPhee et al., 2007) was selected for inclusion in the experiment based on the experience and recommendation of Howard Nelson of Central Washington Grain Growers. Windham is a yellow pea with mottled seed coat; with an average 100 -seed weight of $13.8 \mathrm{~g}$. Windham can withstand ambient air temperatures as low as $-18^{\circ} \mathrm{C}$ without undue damage to plant stands (Nelson, 2017). This cultivar has an average mature plant height of $44 \mathrm{~cm}$ with upright growth habit that allows for direct combining at harvest with a conventional header (i.e., swathing and/or a pick-up header not required).

Precipitation was measured on site during all years of the study by the Washington State University (WSU) AgWeatherNet (http://weather.wsu.edu/) with a Campbell Scientific CR-1000 logger and associated hardware. The soil at the site is a Ritzville silt loam (coarse-silty, mixed, superactive, mesic, Calcidic Haploxerolls; Soil Survey Staff, 2010). The soil is more than 2 meters deep to underlying basalt bedrock with uniform texture throughout the profile and with no rocks or restrictive layers. Slope is $<1 \%$. Long-term (100-year) annual precipitation at/near the site averages $292 \mathrm{~mm}$. Annual crop-year (Sept. 1-Aug. 31) precipitation during the study period ranged from 207 to $370 \mathrm{~mm}$ and averaged $277 \mathrm{~mm}$.

\section{Treatments and Field Operations}

Throughout the 6-year experiment, glyphosate herbicide was applied at a rate of $0.48 \mathrm{~kg}$ acid equivalent (ae)/ha in March to control weeds in the undisturbed residue of the WP, WW, and SW plots that had been harvested the previous July or August. The two 3-year crop rotations in the experiment were (i) WP-SW-SF vs. (ii) WW-SW-SF. Experimental design was a randomized complete block with four replicates. All phases of both rotations were present every year for a total of 24 individual plots. Size of individual plots was $5 \times 30 \mathrm{~m}$.

During the fallow year, conservation primary spring tillage was conducted with a Haybuster ${ }^{\mathrm{TM}}$ undercutter implement in mid-to-late May at a depth of $10 \mathrm{~cm}$. For the WW-SW$\mathrm{SF}$ treatment, $56 \mathrm{~kg} / \mathrm{ha}$ aqua $\mathrm{NH}_{3}-\mathrm{N}+11 \mathrm{~kg} / \mathrm{ha}$ thiosol $\mathrm{S}$ fertilizer was injected with the undercutter implement during primary spring tillage. No fertilizer was applied to the WP-SWSF treatment with the undercutter during primary spring tillage. Summer fallow in both treatments was rodweeded once in July at a depth of $8 \mathrm{~cm}$ to control broadleaf weeds.

Winter pea (cv. Windham) and WW (cv. Xerpha) were planted at the same time and depth each year in either the last week of August or first week of September with a deep-furrow drill with $43 \mathrm{~cm}$ spacing between rows. Seed was inoculated with powdered rhizobium bacteria at time of planting to facilitate root nodulation and fixation of atmospheric nitrogen. Seeding rate for WP was $100 \mathrm{~kg} / \mathrm{ha}\left(70\right.$ seeds $\left./ \mathrm{m}^{2}\right)$ and for WW $56 \mathrm{~kg} / \mathrm{ha}$ $\left(160\right.$ seeds $\left./ \mathrm{m}^{2}\right)$. An average of $10 \mathrm{~cm}$ of soil covered the seeds. Excellent stands of both WP and WW were achieved every year. 
Spring wheat (cv. Louise) was planted and fertilized in late March in one-pass directly into the undisturbed soil and residue left from the previous WP or WW crop. A no-till hoe-opener drill was used to place seed in paired rows $10-\mathrm{cm}$ apart with $30 \mathrm{~cm}$ spacing between openers. Fertilizer was placed in a band between and $3 \mathrm{~cm}$ below the paired rows. Seeding rate for SW was 78 $\mathrm{kg} / \mathrm{ha}\left(225\right.$ seeds $\left./ \mathrm{m}^{2}\right)$ and soil covering the seed averaged $2 \mathrm{~cm}$. Prior to SW planting and fertilization, soil samples were obtained from 2,014 to 2,106 in 30-cm increments from the middle of each plot to a depth of $120 \mathrm{~cm}$ in all four replicates, then combined to make one sample for each treatment per depth increment, where the previous crop was WP or WW. Soil samples were then analyzed for N, P, K, S, and other nutrients at a commercial soiltesting laboratory (Soil Test Farm Consultants, Inc., Moses Lake, WA). Fertilizer rate for SW was based on soil test residual soil fertility, available soil water, and perceived grain yield potential. Potassium fertilizer was not required as soils contain naturally adequate quantities of this nutrient. Although soil fertility values following WP vs. WW differed somewhat (Table 1), SW after either WP or WW always received the same fertilizer application rate each year. Solution $32\left(\mathrm{NH}_{4} \mathrm{NO}_{3}+\right.$ urea $)$ provided the liquid fertilizer base to supply an average of $38 \mathrm{~kg} \mathrm{~N}, 7 \mathrm{~kg} \mathrm{P}$ (aqueous solution of $\mathrm{NH}_{4} \mathrm{H}_{2} \mathrm{PO}_{4}$ ), and $10 \mathrm{~kg} \mathrm{~S}$ [aqueous solution of $\left.\left(\mathrm{NH}_{4}\right)_{2} \mathrm{~S}_{2} \mathrm{O}_{3}\right] /$ ha. Excellent stands of SW were achieved every year.

Crop yields were determined in early-to-mid July (WP) and early August (WW and SW) by harvesting a $1.5-\mathrm{m}$ swath through the center of each 30-m-long plot with a Hege ${ }^{\mathrm{TM}} 140$ plot combine. After grain harvest with the plot combine, the remaining standing crops in the experiment were harvested with a commercial-size combine.

\section{In-Crop and Post-Harvest Weed Control with Herbicides}

When WP reached the three-leaf (or four-node) stage of growth in April, $1.1 \mathrm{~kg}$ active ingredient (ai)/ha sodium salt of bentazon broadleaf-weed herbicide was tank mixed with $0.1 \mathrm{~kg}$ ai $/ \mathrm{ha}$ quizalofop P-ethyl grass-weed herbicide and applied. Bentazon and MCPA Amine are currently the only non-soil-residual broadleaf-weed herbicides labeled for use in WP. The major grass weeds of concern in the region are downy brome and jointed goatgrass. Both these grass weeds are winter annuals with growth cycles similar to WW and are particularly problematic in the 2-year WW-SF rotation (Young and Thorne, 2004).

Herbicides used to control broadleaf weeds in WW were either 2,4-D ester at a rate of $0.84 \mathrm{~kg}$ acid equivalent (ae)/ha or $0.56 \mathrm{~kg}$ ai/ha bromoxynil applied in April after WW had four tillers but before the "jointing" stage of WW growth development. In-crop broadleaf herbicides used for SW were $0.56 \mathrm{~kg}$ ai $/$ ha bromoxynil or $0.45 \mathrm{~kg}$ ai/ha bromoxynil $+0.02 \mathrm{~L}$ ai/ha thifensulfuron applied in May.

Glyphosate was applied at a rate of $0.90 \mathrm{~kg}$ ae $/$ ha following the harvest of SW in August of 2014 and 2015 (the two driest crop years) to control Russian thistle (Salsola tragus L.). Post-harvest herbicide application was not required for WP or WW in any year.
TABLE 1 | Soil nitrate-N, Olsen-P, sulfate-S, and soil organic matter (SOM) in late March during 3 years after either winter pea or winter wheat and prior to planting spring wheat.

\begin{tabular}{|c|c|c|c|c|}
\hline & $\begin{array}{c}\text { Nitrate } \\
(\mathrm{mg} / \mathrm{kg} / 120 \mathrm{~cm})\end{array}$ & $\begin{array}{l}\text { Phosphorus } \\
\text { (mg/kg/30 cm) }\end{array}$ & $\begin{array}{c}\text { Sulfate } \\
(\mathrm{mg} / \mathrm{kg} / 90 \mathrm{~cm})\end{array}$ & $\begin{array}{c}\text { SOM } \\
(30 \mathrm{~cm}, \%)\end{array}$ \\
\hline \multicolumn{5}{|l|}{2013} \\
\hline Winter wheat & 24 & 53 & 39 & 1.7 \\
\hline Winter pea & 30 & 52 & 45 & 1.5 \\
\hline \multicolumn{5}{|l|}{2014} \\
\hline Winter wheat & 16 & 35 & 17 & 1.8 \\
\hline Winter pea & 22 & 38 & 17 & 1.6 \\
\hline \multicolumn{5}{|l|}{2016} \\
\hline Winter wheat & 17 & 45 & 16 & 1.4 \\
\hline Winter pea & 24 & 43 & 13 & 1.6 \\
\hline
\end{tabular}

\section{Soil Water}

Soil water was measured to a depth of $180 \mathrm{~cm}$ three times each year: (i) in early August immediately after WP, WW, and SW grain harvest (16 plots); (ii) at the end of fallow in late August for the SF plots (8 plots); and (iii) in mid-March (all 24 plots). Volumetric soil water content in the $0-30-\mathrm{cm}$ depth was determined from two $15-\mathrm{cm}$ core samples with gravimetric procedures (Topp and Ferre, 2002) using known soil bulk density values for these depths. Soil volumetric water content in the 30$180-\mathrm{cm}$ depth was measured in $15-\mathrm{cm}$ increments by neutron thermalization (Hignett and Evett, 2002).

\section{Market Price, Gross Returns, and Adjusted Gross Returns}

Gross returns for WP and WW per hectare were calculated based on the yield results for each year of the study. Edible WP grown by farmers in eastern Washington was sold through a "market pool" operated by Central Washington Grain Growers in Wilbur, WA. Market streams for WP through the years included seed for cover crops, US government food aid, export for food to Asia, and for pet food. Winter pea marketing pool prices ranged from 160 to 339 US\$/metric ton (MT).

Soft white wheat market price used was the price offered during the first week of September for each year of the study at Ritzville Warehouse, Ritzville, WA. Ritzville Warehouse accepts $\mathrm{WW}$ and WP for storage and is the closest commercial elevator delivery site for the study. Gross returns per hectare for both WP and WW were calculated by multiplying yields obtained from the study by the market prices for each year. Adjusted gross returns were then calculated for both rotations by tabulating for each year the cost of N and S used for WW (but not for WP) and any differences in SW yields.

\section{Statistical Analysis}

Statistical analyses using a randomized complete block design analysis of variance (ANOVA) were conducted for: (i) water use of WP vs. WW as well as overwinter storage of precipitation in the soil following these two crops averaged over 5 years, and; (ii) within-year and 5-year average differences in SW grain yield 
following either WP or WW. A split-plot in time ANOVA was used for the 5-year average soil water data and the 5-year average SW yield data with treatment as the fixed effect factor and year as the random effect factor. The least significant difference test was used to detect statistical differences in treatment means. All ANOVA tests were done at the $5 \%$ level of significance.

\section{RESULTS}

\section{Soil Water}

Averaged over the years, WP used an average of $30 \mathrm{~mm}$ less soil water than WW $(P<0.001$, Table 2$)$. The majority of this water savings with WP occurred at soils depths below $100 \mathrm{~cm}$ (Figure 1) as WP roots do not reach this depth. These data on soil water use by WP agree closely with those reported by Miller and Holmes (2012) in Montana and Merrill et al. (2004) in North Dakota. However, by late March, WP plots had only $13 \mathrm{~mm}$ more soil water than WW plots (Table 2) because: (i) the greater the surface residue cover, the more water will be stored in the soil (e.g., WP produces little residue compared to WW); and (ii) the drier the soil, the more overwinter precipitation will be stored in the soil (Kok et al., 2009).

The overwinter precipitation storage efficiency (PSE) in the soil averaged 55 and $69 \%$ for WP and WW plots, respectively (Table 2). Similar overwinter PSE-values were reported following spring lentil (Lens culinaris L.) vs. following SW in a 21-year study in Saskatchewan (Campbell et al., 2007). This increase in overwinter PSE for WW over WP plots occurred within the first $100 \mathrm{~cm}$ of the soil profile whereas the relative difference in spatial water distribution at the $100-180-\mathrm{cm}$ depths remained about the same for WP and WW plots (Figure 1). The end result, however, was that when SW was planted in late March, average overwinter soil water content was 290 and $277 \mathrm{~mm}$ following WP and WW, respectively (Table $\mathbf{1}$ ).

\section{Soil Nitrate-N}

When measured in late March, soil nitrate- $\mathrm{N}$-values trended higher after a crop of WP compared to WW, despite the fact that zero $\mathrm{N}$ was applied for WP and $56 \mathrm{~kg}$ of N/ha was applied for WW (Table 1). This can be explained by the fact that WP is a legume that fixes atmospheric nitrogen. Although statistical analysis was not possible (soil samples were pooled from the four replicates), nitrate-N-values were $25-41 \%$ greater following WP vs. WW.

\section{Grain Yield}

Yield of WP ranged from 1,696 to 3,158 kg/ha and averaged 2,443 $\mathrm{kg} /$ ha over 5 years (Table 3 ). Winter pea was killed by $-21^{\circ} \mathrm{C}$ air temperatures with no snow cover in 2014 and was replaced by spring pea (cv. Banner) which yielded $870 \mathrm{~kg} / \mathrm{ha}$. Winter wheat grain yield ranged from 3,372 to $5,841 \mathrm{~kg} / \mathrm{ha}$ for an average of $4,878 \mathrm{~kg} /$ ha over 6 years (Table 3 ).

Spring wheat grain yield was significantly greater following WP vs. following WW in 2013 and 2015. The 5-year average SW grain yield of $2,298 \mathrm{~kg} / \mathrm{ha}$ following WP was significantly different from 2,122 kg/ha following WW (Table 3).
TABLE 2 | (i) Soil water content to a depth of $180 \mathrm{~cm}$ measured after harvest of winter pea and winter wheat and again in late March following these two crops; (ii) overwinter gain in soil water, and; (iii) overwinter precipitation storage efficiency in the soil (PSE).

\begin{tabular}{lcccc}
\hline & $\begin{array}{c}\text { Beginning } \\
\text { (late Aug.) }\end{array}$ & $\begin{array}{c}\text { Spring (late } \\
\text { Mar.) }\end{array}$ & $\begin{array}{c}\text { Overwinter } \\
\text { gain }\end{array}$ & PSE (\%) \\
\hline Soil water content (mm) & & & \\
Winter pea & 180 & 290 & 110 & 55 \\
Winter wheat & 150 & 277 & 127 & 69 \\
$P$-value & $<0.001$ & $n$ & 0.001 & \\
\hline
\end{tabular}

Data are averaged over 5 years. Average overwinter precipitation was $164 \mathrm{~mm}$.

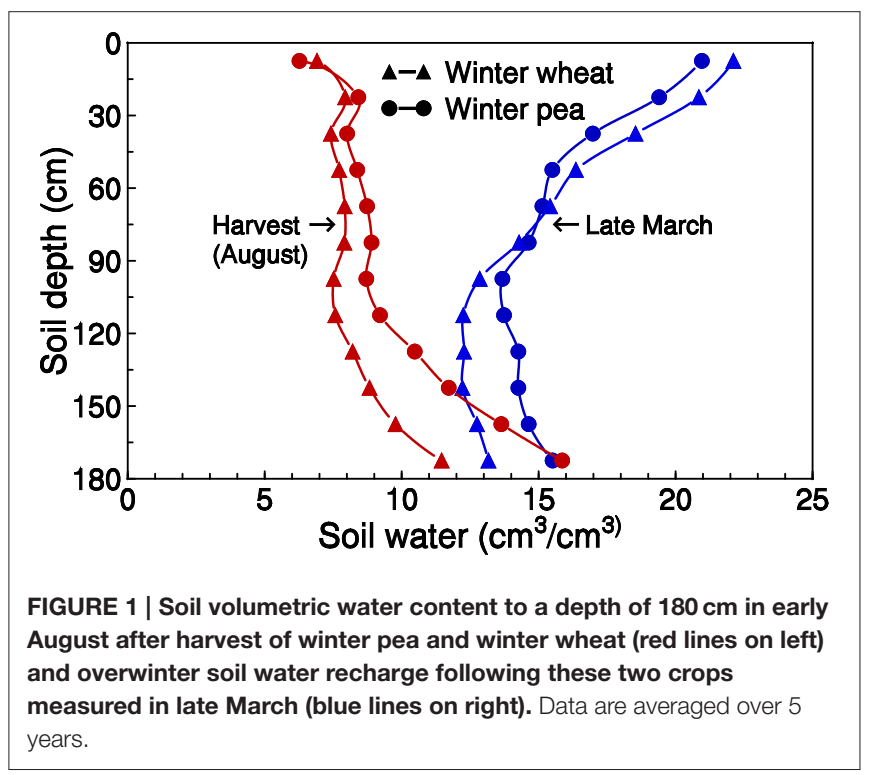

\section{Market Price, Gross Returns, and Adjusted Gross Returns}

Gross returns for WW exceeded that for WP in most years (Table 4). However, cost of $56 \mathrm{~kg} / \mathrm{ha}$ aqua $\mathrm{NH}_{3}-\mathrm{N}+11 \mathrm{~kg} / \mathrm{ha}$ thiosol S fertilizer for WW (where none was used for WP) ranged from $\$ 66$ to $\$ 97 /$ ha and averaged $\$ 86 /$ ha over the 6 years (actual costs paid for the fertilizer each year). Also, SW yield after WP vs. WW from 2012 to 2016 ranged from -143 to $+589 \mathrm{~kg} / \mathrm{ha}$ and averaged $+176 \mathrm{~kg} / \mathrm{ha}$ (Table 3 ). Using the commodity market prices shown in Table 4, SW after WP generated from $-\$ 35$ to $+\$ 85 /$ ha and averaged $+\$ 39 /$ ha more return than SW after WW. Thus, the fertilizer savings plus the greater SW grain yield revenue provided in the WP rotation should be considered rather than just the gross returns shown in Table 4.

\section{DISCUSSION}

Winter wheat-summer fallow has been the dominant cropping system practiced throughout the low-precipitation dryland cropping region of east-central Washington and north-central Oregon for well-over 100 years. Despite long-term and ongoing 
TABLE 3 | Yield of winter pea (WP) and winter wheat (WW) as well as the subsequent yield of spring wheat (SW) following both WP and WW over a 6-year period at Ritzville, WA.

\begin{tabular}{|c|c|c|c|c|c|c|c|}
\hline & \multicolumn{7}{|c|}{ Grain yield (kg/ha) } \\
\hline & 2011 & 2012 & 2013 & 2014 & 2015 & 2016 & Avg. \\
\hline \multicolumn{8}{|c|}{ WINTER CROP } \\
\hline Winter pea & 2,193 & 3,158 & 2,336 & $\ldots{ }^{*}$ & 1,696 & 2,833 & $2,443^{\star \star}$ \\
\hline Winter wheat & 5,180 & 5,729 & 5,841 & 3,372 & 4,211 & 4,932 & 4,878 \\
\hline \multicolumn{8}{|c|}{ SPRING CROP ${ }^{* \star \star}$} \\
\hline SW after WP & & 2,010 & $2,992 \mathrm{a}$ & 1,043 & $2,293 \mathrm{a}$ & 3,151 & $2,298 a$ \\
\hline SW after WW & & 2,153 & $2,700 \mathrm{~b}$ & 965 & $1,704 b$ & 3,086 & $2,122 b$ \\
\hline \multicolumn{8}{|c|}{ Crop-year precipitation (mm) } \\
\hline & 330 & 294 & 254 & 207 & 208 & 370 & 277 \\
\hline
\end{tabular}

Values at the bottom show crop-year (Sept. 1-Aug. 31) precipitation at the site.

"WP was winterkilled in 2014 and replanted to Banner edible spring pea, which yielded $870 \mathrm{~kg} / \mathrm{ha}$.

** Winter pea average yield is for 5 years (i.e., 2014 not included).

${ }^{* * *}$ ANOVA is for SW only. Within-column means followed by a different letter are significantly different at $P<0.05$

TABLE 4 | Ritzville soft white wheat market prices during the first week of September and winter pea market pool price as well as gross return for these crops based on the yield results of the experiment from 2011 to 2016.

\begin{tabular}{|c|c|c|c|c|}
\hline & \multicolumn{2}{|c|}{ Commodity market price (US\$/MT)* } & \multicolumn{2}{|c|}{ Gross returns (US\$/hectare)* } \\
\hline & $\begin{array}{l}\text { Soft white } \\
\text { wheat }\end{array}$ & Winter pea & $\begin{array}{l}\text { Soft white } \\
\text { wheat }\end{array}$ & Winter pea \\
\hline 2011 & 198 & 291 & 1,245 & 776 \\
\hline 2012 & 242 & 289 & 1,680 & 1,112 \\
\hline 2013 & 202 & 339 & 1,433 & 963 \\
\hline 2014 & 172 & No pool, winterkill & 701 & $\cdots$ \\
\hline 2015 & 145 & 377 & 746 & 778 \\
\hline 2016 & 123 & 160 & 731 & 674 \\
\hline
\end{tabular}

*Soft white wheat price data from Ritzville Warehouse, Ritzville, WA. Winter pea market pool price data from Howard Nelson, Central Washington Grain Growers, Wilbur, WA.

${ }^{\star *}$ Gross return values shown here to not account for cost of $N$ and $S$ used for WW (but not used for WP) or the additional revenue from greater SW yield after WP vs. WW (see Results section).

efforts, farmers and scientists have not yet identified any springplanted crop, including SW spring barley (Hordeum vulgare L.), and numerous others, that can provide the yield stability and economic viability of WW-SF.

A big benefit of growing WP in wheat-based cropping systems is the opportunity for in-crop control of winter-annual grass weeds such as downy brome and jointed goatgrass. These two grass weeds have growth cycles similar to WW and infestations are frequently heavy and troublesome (Appleby and Morrow, 1990), especially in the 2-year WW-SF rotation.

Another benefit of WP is its large seed size and strong "push" by the elongating hypocotyl which enables it to emerge from deep planting depths. For optimum grain yield potential, farmers in east-central Washington seed WW into SF as deep as $20 \mathrm{~cm}$ below the soil surface with deep-furrow drills to reach adequate soil moisture in late August-early September, and WW seedlings need to emerge through as much as $15 \mathrm{~cm}$ of dry soil cover. Data from planting-date experiments in east-central Washington suggest that late August-early September is also the best planting time for optimum yield potential of WP (Rebecca McGee, personal communication). Experience of farmers and scientists strongly demonstrates that WP seedlings can emerge from even deeper planting depths than WW. In addition, WP seedlings easily emerge through surface soil that has been crusted by rain showers whereas WW seedlings cannot do so.

A new yellow WP cultivar "Blaze" (ProGene Plant Research, Othello, WA) is presently under seed multiplication and will be available to farmers in 2018. Compared to Windham in regional trials, Blaze has (i) $13 \%$ higher yield, (ii) $18 \mathrm{~cm}$ taller plant height at maturity, 22\% larger seed, and (iii) better cold tolerance (Nelson, 2017). For example, during a cold event of $-18^{\circ} \mathrm{C}$ with no snow cover in 2014 , Windham was winterkilled at regional locations whereas, at these same locations, Blaze survived (Nelson, 2017). It is estimated that Blaze has similar cold tolerance as regionally-adopted WW cultivars. Additionally, three advanced WP numbered lines in the USDA-Agricultural Research Service legume breeding program in Pullman, WA show excellent potential and are expected to be released soon. These numbered WP lines have better cold tolerance than Windham in addition to smooth seed coat, clear hilum, and large seed size that are deemed highly desirable for food markets (Rebecca McGee, personal communication).

A soil management concern about growing WP is the fact that they produce very little durable residue. Wind erosion and dust emission from agricultural soils is a major environmental and air quality concern in east-central Washington (Sharratt and Vaddella, 2012). Wind tunnel studies during the fallow year after the oilseed crops camelina (Camelina sativa L. Crantz) and safflower (Carthamus tinctorius L.) showed up to $250 \%$ greater blowing dust emissions even using best management practices for tillage-based SF compared to after WW (Sharratt and Schillinger, 2014). Personal observation suggests that WP residue decomposes at about the same rate as residue of camelina and safflower. In a practical sense, this means that farmers must be especially judicious in protecting the soil after WP by either (i) recropping to the spring crop (as done in this study), or (ii) conducting no tillage during the 13-month SF cycle.

There are currently few effective in-crop broadleaf herbicide options for WP. Bentazon herbicide (used every year in WP in the study) provides little control for tumble mustard (Sisymbrium altissimum L.) or tansy mustard (Descurainia pinnata L.). Although considered minor weeds that are easily controlled with herbicides in WW, both were present in minor to moderate levels in WP. The soil residual imazamox herbicide can be used in WP and is used by many farmers who practice the Clearfield ${ }^{\mathrm{TM}}$ method for WW production. However, many farmers are reluctant to use soil-residual herbicides due to limitations imposed on rotation to other crops or to WW cultivars that are not tolerant of this herbicide. Russian thistle, by far the most troublesome broadleaf weed in the region, was not a problem in WP in any year, presumably due to the ability of WP to provide canopy 
closure relatively early in the spring before this weed can establish.

The potential impact of increased pulse crop production on greenhouse gas emissions deserves some discussion. Lemke et al. (2007) and Cutforth et al. (2007) wrote review articles about the impact of pulse crop production on climate change in the Canadian and US northern Great Plains and the contribution of pulse crops to the balance of greenhouse gases. Authors of these papers agreed that rotations which include pulse crops will likely have lower nitrous oxide emissions compared to rotations that do not contain a pulse because legumes fix atmospheric $\mathrm{N}$ compared to rotations that rely solely on fertilizer N. Lemke et al. (2007) and Cutforth et al. (2007) further agreed that replacing a cereal with a pulse crop will likely result in the same or slightly smaller carbon dioxide emissions in direct relation to reduction in fertilizer $\mathrm{N}$ usage.

\section{CONCLUSION}

This study showed that WP has excellent production potential in the typical WW-SF region of east-central Washington. Although gross returns for WW were greater than for WP during most years, adjusted gross returns for the two rotations were equivalent. Winter pea has unsurpassed seedling emergence from deep planting depths, even when surface soils have been crusted by rain showers before emergence. Excellent WP plant stands were consistently achieved that effectively competed against Russian thistle. New WP cultivars will be available to farmers

\section{REFERENCES}

Appleby, A. P., and Morrow, L. A. (1990). "The Pacific Northwest," in Systems of Weed Control in North America. WSSA Monogr, Vol. 6. ed W. W. Donald (Champaign, IL: WSSA), 200-232.

Campbell, C. A., Zentner, R. P., Basnyat, P., Wang, H., Selles, F., McConkey, B. G., et al. (2007). Water use efficiency and water and nitrate distribution in soil in the semiarid prairie: effect of crop type over 21 years. Can. J. Plant Sci. 87, 815-827. doi: 10.4141/CJPS06034

Chen, C., Miller, P., Muehlbauer, F., Neill, K., Wichman, D., and McPhee, K. (2006). Winter pea and lentil response to seeding date and microand macro-environments. Agron. J. 98, 1655-1663. doi: 10.2134/agronj200 6.0085

Cutforth, H. W., McGinn, S. M., McPhee, K. E., and Miller, P. R. (2007). Adaptation of pulse crops in the changing climate of the northern Great Plains. Agron. J. 99, 1684-1699. doi: 10.2134/agronj2006.0310s

Hignett, C., and Evett, S. R. (2002). "Methods for measurement of soil water content: neutron thermalization," in Methods of Soil Analysis. Part 4-Physical Methods, eds J. H. Dane and G. C. Topp (Madison, WI: SSSA), 501-521.

Juergens, L. A., Young, D. L., Schillinger, W. F., and Hinman, H. R. (2004). Economics of alternative no-till spring crop rotations in Washington's wheatfallow region. Agron. J. 96, 154-158. doi: 10.2134/agronj2004.0154

Kok, H., Papendick, R. I., and Saxton, K. E. (2009). STEEP: impact of long-term conservation farming research and education in Pacific Northwest wheatlands. J. Soil Water Cons. 64, 253-264. doi: 10.2489/jswc.64.4.253

Lemke, R. L., Zhong, Z., Campbell, C. A., and Zentner, R. (2007). Can pulse crops play a role in mitigating greenhouse gases from North American agriculture? Agron. J. 99, 1719-1725. doi: 10.2134/agronj2006.0327s

Long, J. A., Lawrence, R. L., Miller, P. R., and Marshall, L. A. (2014). Changes in field-level cropping sequences: indicators of shifting agricultural in 2018 that have cold tolerance similar to that of WW, greater yield potential than $\mathrm{cv}$. Windham, and better quality traits that will fetch higher prices in regional, national, and international markets.

Land area planted of WP in the PNW drylands is still minor, but farmers and scientists are excited about this crop and planted acreage has increased exponentially every year since 2013 . This paper provides the first report in the literature on WP production in the typical WW-SF region of the PNW.

\section{AUTHOR CONTRIBUTIONS}

Contributions to this article were made by WS and he is accountable for the content of the work.

\section{ACKNOWLEDGMENTS}

The author gratefully acknowledges the cooperation and support of Ronald Jirava on whose farm the research was conducted. Excellent field and office support was provided by John Jacobsen, Steve Schofstoll, and Samantha Crow located at the WSU Lind Dryland Research Station. Much appreciation is extended to Howard Nelson and Kurt Braunwart for sharing their knowledge about producing and marketing WP. Funding was provided by the WSU Agricultural Research Center through Hatch Project 0250, the USDANIFA through the REACCH Project, and by ProGene Plant Research. practices. Agric. Ecosyst. Environ. 189, 11-20. doi: 10.1016/j.agee.2014. 03.015

McPhee, K. E., Chen, C. C., Wichman, D. M., and Muehlbauer, F. J. (2007). Registration of "Windham" winter feed pea. J. Plant Regist. 1, 117-118. doi: $10.3198 /$ jpr2006.12.0828crc

Merrill, S. D., Tanaka, D. L., Krupinsky, J. M., and Ries, R. E. (2004). Water use and depletion by diverse crop species on Haplustoll soil in the northern Great Plains. J. Soil Water Conserv. 59, 176-183.

Miller, P. R., Bekkerman, A., Jones, C. A., Burgess, M. H., Holmes, J. A., and Engel, R. E. (2015). Pea in rotation with wheat reduced uncertainty of economic returns in southwest Montana. Agron. J. 107, 541-550. doi: 10.2134/agronj14.0185

Miller, P. R., Gan, Y., McConkey, B. G., and McDonald, C. L. (2003). Pulse crops for the Northern Great Plains: II. Cropping sequence effects on cereal, oilseed, and pulse crops. Agron. J. 95, 980-986. doi: 10.2134/agronj20 03.0980

Miller, P. R., and Holmes, J. A. (2012). Comparative soil water use by annual crops at a semiarid site in Montana. Can. J. Plant Sci. 92, 803-807. doi: 10.4141/cjps2011-191

NASS (2017). Northwest Regional Field Office. National Agricultural Statistics Service. Washington, DC: USDA. Available online at: https://www.nass.usda.gov/Statistics_by_State/Washington/index.php

Nelson, H. (2017). Central Washington Grain Growers 2016 Test Plot Results. Available online at: http://www.cwgg.net/images/603/2016 TestPlotResults.pdf (Accessed Feb 17, 2017).

Sharratt, B., and Schillinger, W. F. (2014). Windblown dust potential from oilseed cropping systems in the Pacific Northwest United States. Agron. J. 106, 1147-1152. doi: 10.2134/agronj13.0384

Sharratt, B. S., and Vaddella, V. K. (2012). Threshold friction velocity of soils within the Columbia Plateau. Aeolian Res. 6, 13-20. doi: 10.1016/j.aeolia.2012.06.002 
Statistics Canada (2017). Ottawa. Available online at: http://www.statcan.gc.ca/ eng/start

Strydhorst, S., Olson, M. A., Vasanthan, T., McPhee, K. E., McKenzie, R. H., Henriques, B., et al. (2015). Adaptability and quality of winter pea and lentil in Alberta. Agron. J. 107, 2431-2448. doi: 10.2134/agronj15-0092

Soil Survey Staff (2010). Keys to Soil Taxonomy, 11th Edn. Washington, DC: USDA-Natural Resources Conservation Service.

Topp, G. C., and Ferre, P. A. (2002). "Methods for measurement of soil water content: Thermogravimetric using convective oven-drying," in Methods of Soil Analysis. Part 4-Physical Methods. SSSA Book Series: 5, eds J. H. Dane and G. C.Topp (Madison, WI: Soil Science Society of America), 422-424.

Young, F. L., and Thorne, M. E. (2004). Weed-species dynamics and management in no-till and reduced-till fallow cropping systems for the semi-arid agricultural region of the Pacific Northwest, USA. Crop Prot. 23, 1097-1110. doi: $10.1016 /$ j.cropro.2004.03.018

Conflict of Interest Statement: The author declares that the research was conducted in the absence of any commercial or financial relationships that could be construed as a potential conflict of interest.

Copyright (C) 2017 Schillinger. This is an open-access article distributed under the terms of the Creative Commons Attribution License (CC BY). The use, distribution or reproduction in other forums is permitted, provided the original author(s) or licensor are credited and that the original publication in this journal is cited, in accordance with accepted academic practice. No use, distribution or reproduction is permitted which does not comply with these terms. 